\title{
The relationship between the low Apgar scores of the newborns and hematologic parameters which are inflammatory markers
}

\author{
Gökhan Karakoç ${ }^{1}$ (D), Serenat Eriş Yalçın² (D) , And Yavuz² (D) , Çağatayhan Öztürk ${ }^{3}$ (D) , Aykan Yücel ${ }^{3}$ \\ ${ }^{1}$ Perinatology Clinic, Atatiirk Training and Research Hospital, Izmir Katip Çelebi University, Izmir, Turkey \\ ${ }^{2}$ Perinatology Clinic, Antalya Training and Research Hospital, Antalya, Turkey \\ ${ }^{3}$ Perinatology Clinic, Etlik Ziibeyde Hanım Gynecology Training and Research Hospital, Ankara, Turkey
}

\begin{abstract}
Objective: To investigate the relationship between the 5 -minute Apgar scores of the newborns checked in the cases induced due to prolonged pregnancy and neutrophil-lymphocyte ratio (NLR) and platelet-lymphocyte ratio (PLR), and to investigate the contributions of these parameters as prognostic markers in the low Apgar scores.

Methods: A total of 169 primigravida cases for which delivery by induction was decided due to prolonged pregnancy after they completed 41 weeks of gestation between 2017 and 2018 were included in the study. The detailed previous histories of all cases were obtained at admission and they underwent cervicovaginal examination, obstetric ultrasonography for the assessment of fetal biometry and amniotic fluid, and complete blood count including hemoglobin level, total white blood cell count, differential leukocyte number and platelet count. NLR and PLR were calculated as the ratio of neutrophil number to lymphocyte number and the ratio of platelet number to lymphocyte number, respectively. The Apgar scores in the newborn assessment were determined according to the usual criteria 1 and 5 minutes after the birth. The independent samples t-test, Mann-Whitney $U$ test and chi-square test were used for the analysis of the data.

Results: The mean NLR and PLR values of the cases were calculated $4.8 \pm 2.8$ and $148.8 \pm 74.9$, respectively. While $108(64 \%)$ patients delivered vaginally, $61(36 \%)$ patients delivered by cesarean section. The Apgar score was $>7$ in 142 (84\%) patients and $<7$ in 27 (16\%) patients. NLR and PLR values were significantly higher in the group with Apgar score $<7$ than the group with Apgar score $\geq 7(\mathrm{p}<0.05)$.

Conclusion: The elevations in NLR and PLR is the usual part of a health pregnancy; however, excessively elevated inflammation has been associated with poor prenatal and developmental outcomes in various populations. In conclusion, these markers can be used as the parameters helping clinicians to predict poor obstetric outcomes.
\end{abstract}

Keywords: Inflammation, neutrophil-lymphocyte ratio, plateletlymphocyte ratio.

\section{Özet: İnflamatuar belirteç olan hematolojik parametrelerin yenidoğan düşük Apgar skorları ile ilişkisi}

Amaç: Uzamış gebelik nedeni ile indüklenen olgularda bakılan yenidoğan 5. dakika Apgar skoru ile nötrofillerin lenfositlere oranı (NLR) ve trombositlerin lenfositlere oranı (PLR) arasındaki ilişkiyi araştırmak ve bu parametrelerin düşük Apgar skorlarında prognostik belirteç olarak katkılarını incelemektir.

Yöntem: 2017-2018 yılları arasında 41. gebelik haftasını tamamlayarak uzamış gebelik nedeniyle indüksiyon ile doğum kararı alınan 169 primigravid olgu çalışmaya dahil edildi. Tüm olgular kabul anında ayrıntılı öykü alma, servikovajinal muayene, fetal biyometri ve amniyotik sıvı değerlendirmesi için obstetrik ultrason ve hemoglobin düzeyi, toplam beyaz küre sayımı, diferansiyel lökosit sayısı ve trombosit sayımı dahil tam kan sayımlarına tabi tutuldu. NLR ve PLR sırasıyla nötrofil sayısının lenfosit sayısına oranı ve trombosit sayısının lenfosit sayısına oranı olarak hesaplandı. Yenidoğanın değerlendirilmesinde Apgar skorları doğumdan bir ve beş dakika sonra olağan kriterlere göre tayin edildi. Verilerin analizinde bağımsız örneklem t testi, Mann-Whitney U ve ki-kare testleri kullanild1.

Bulgular: Hastaların ortalama NLR değerleri $4.8 \pm 2.8$, PLR değerleri $148.8 \pm 74.9$ olarak saptand, $108(\% 64)$ hasta vajinal yolla doğum yaparken, 61 (\%36) hastada sezaryen ile doğum gerçekleşti. 142 (\%84) hastada Apgar skoru >7 iken, 27 (\%16) hastada <7 olarak belirlendi. Apgar $<7$ olan grupta NLR ve PLR değerleri Apgar $\geq 7$ olan gruptan anlamlı $(\mathrm{p}<0.05)$ olarak daha yüksekti.

Sonuç: NLR ve PLR'deki yükselmeler, sağlıklı gebeliğin olağan bir parçasıdır ancak aşırı artmış inflamasyon, çok çeşitli popülasyonlarda olumsuz doğum ve gelişimsel sonuçlarla ilişkili bulunmuştur. Sonuç olarak, bu belirteçler kötü obstetrik sonuçları öngörmede klinisyenlere yardımcı olan parametreler olarak kullanılabilir.

Anahtar sözcükler: İnflamasyon, nötrofil lenfosit oranı, trombosit lenfosit oranı.

Correspondence: Serenat Eriş Yalçı, MD. Perinatology Clinic, Antalya Training and Research Hospital, Antalya, Turkey. e-mail: serenateris@hotmail.com / Received: February 21, 2020; Accepted: June 13, 2020

Please cite this article as: Karakoç G, Eriş Yalçın S, Yavuz A, Öztürk Ç, Yücel A. The relationship between the low Apgar scores of the newborns and hematologic parameters which are inflammatory markers. Perinatal Journal 2020;28(3):157-163. doi:10.2399/prn.20.0283002 


\section{Introduction}

The post-term pregnancy is defined as the pregnancy that takes more than 294 days or 42 weeks as of the beginning of the last menstrual period, and the prolonged pregnancy is defined as the pregnancy that takes more than 287 days or 41 weeks. The prolonged pregnancy is associated with the increase in the fetal and neonatal morbidity and mortality risks. ${ }^{[1]}$ Therefore, the international guidelines recommend inducing labor at $41-41$ weeks of gestation. ${ }^{[2]}$

The Apgar test is a simple and reproducible method used to evaluate the physical condition and health of a newborn right after the birth and to determine any urgent need for the extra care. Five factors are used to evaluate the newborn condition, and each factor is scored between 0 and 2, where 2 is the best score for each of them. The scoring is based on the heart rate, ventilatory effort, skin color, muscle tone and reflex irritability measurements. ${ }^{[3]}$ The final score is between 0 and 10 , and 10 is the maximum possible score. Total score between 7 and 10 is considered "normal", and the low Apgar score indicates the depressed vitality. Apgar scoring is done twice, where the first one is done one minute after the birth and second one is five minutes after the birth. If, rarely, there are concerns about the condition of newborn and first two scores are below 7, the scoring is done 10,15 and 20 minutes after the birth as well..$^{[4,5]}$ 1-minute Apgar score may indicate sudden resuscitation need, and 5-minute Apgar score is an indication of the newborn mortality and various neurological outcomes. There are many factors affecting Apgar score such as the sedation and anesthesia of mother, gestational age during delivery, breech presentation, low birth weight, congenital malformation, presence of comorbid conditions such as maternal hypertensive disorders and different assessments between observers. ${ }^{[6]}$

Neutrophil-lymphocyte ratio (NLR) and plateletlymphocyte ratio (PLR) are the inflammatory ratios that can be calculated easily through a simple blood count. In various medical disciplines, they are frequently reported and tested as the prognostic factors. Many studies investigated these rates in cardiology, oncology, surgery and gastroenterology fields and usually included them into prognostic algorithms. ${ }^{[7-10]}$ In a gynecology-related literature, NLR and PLR were evaluated in gynecologic cancers and reproduction morbidities such as ovarian hyper- stimulation syndrome, premature ovarian insufficiency and endometriosis. ${ }^{[11-14]}$ In the obstetrics, it was reported that NLR elevated in hyperemesis gravidarum, gestational diabetes, preeclampsia, pregnancy-related intrahepatic cholestasis and other diseases. ${ }^{[15-18]}$ Based on these studies, the interpretation of the elevated values during pregnancy has become important.

The objective of this study is to investigate the relationship between NLR and PLR values calculated by the simple blood count parameters and 5-minute Apgar scores of newborns in the cases induced due to the prolonged pregnancy and their contributions as prognostic markers in the low Apgar scores.

\section{Methods}

The primigravida cases for which delivery by induction was decided due to prolonged pregnancy after they completed 41 weeks of gestation between 2017 and 2018 were included in our study. The gestational age was calculated based on the first day of the last menstrual period, and it was confirmed by measuring crown-rump length (CRL) in the ultrasonography examination performed before 14 weeks of gestation.

The cases whose weeks of gestation were unclear, those with irregular cycles, the cases who did not undergo first-trimester ultrasonography examination, and the patients who were classified under high risks due to various reasons such as multiple pregnancy, fetal anomaly, fetal growth restriction, positive indirect Coombs test, documented exposure to an infectious disease that may be transmitted to fetus, hypertension and gestational diabetes during the current pregnancy were excluded from the study.

The detailed previous histories of all cases were obtained at admission and they underwent cervicovaginal examination, obstetric ultrasonography for the assessment of fetal biometry and amniotic fluid, and complete blood count including hemoglobin level, total white blood cell count, differential leukocyte number and platelet count. All blood counts were conducted by a single laboratory using the same automatic computed technology (Autoslide and Siemens ADVIA 2120i Hematology System, Erlangen, Germany). NLR and PLR were calculated as the ratio of neutrophil number to lymphocyte number and the ratio of platelet number to lymphocyte number, respectively. 
The sex and weight of newborn, delivery type, reasons for performing cesarean section, and the need for neonatal intensive care were recorded. The Apgar scores in the newborn assessment were determined according to the usual criteria 1 and 5 minutes after the birth. The cases with high fever and suspected chorioamnionitis during the labor induction, the cases for which emergency cesarean section was preferred due to the indications such as fetal distress and ablatio previa that may affect Apgar score and the cases which underwent general anesthesia during the cesarean section were excluded from the study. The informed consents of all cases included in the study, which was approved by the local ethics committee (ethics committee no: 07.01.2017-01), were obtained.

The statistical method: The descriptive statistics of the data were presented by mean values, standard deviation, median values, the minimum and maximum values, frequency and percentage values. The distribution of the variables were analyzed by Kolmogorov-Smirnov test. The independent samples t-test and Mann-Whitney U test were used for the analysis of quantitative independent data. The qualitative independent data were analyzed by the chi-square test. SPSS (Statistical Package for the Social Sciences) version 22.0 (SPSS Inc., Chicago, IL, USA) was used for the analyses.

\section{Results}

A total of 236 patients were evaluated. After applying the exclusion criteria, 169 patients could be included in the study. The mean NLR and PLR values of the patients were $4.8 \pm 2.8$ and $148.8 \pm 74.9$, respectively. While 108 (64\%) patients delivered vaginally, 61 (36\%) patients delivered by cesarean section. The cephalopelvic disproportion and non-progressive labor were the indications of cesarean section. The Apgar score was $>7$ in 142 (84\%) patients and $<7$ in $27(16 \%)$ patients (Table 1). $33.3 \%$ of 27 cases with Apgar score $<7$ were observed in the newborns delivered vaginally and $66.7 \%$ of them in the newborns delivered by cesarean section. There was no significant difference between the groups in terms of newborn weight, newborn sex, and the cervical dilation procedure used $(\mathrm{p}>0.05)$. The rate of cesarean section was significantly higher in the group with Apgar score $<7$ than the group with Apgar score $\geq 7(\mathrm{p}<0.05)$. NLR and PLR values were significantly higher in the group with Apgar score $<7$ than the group with Apgar score $\geq 7$ $(\mathrm{p}<0.05)$ (Table 2 and Fig. 1).

\section{Discussion}

In the recent years, various studies have focused on neutrophil-lymphocyte ratio (NLR) which shows the ratio of the neutrophils which initiate the first defense line and represent the active non-specific inflammatory mediator to the lymphocytes representing the regulatory or protective component of inflammation. ${ }^{[19]}$ It provides prognostic and diagnostic information about the sub-clinical inflammation beyond conventional risk factors. It is a reliable indicator of the low level inflammation under various clinical conditions. The platelets and lymphocytes are the significant blood parameters about

Table 1. Demographic data.

\begin{tabular}{|c|c|c|c|}
\hline & Min-max & Median & Mean \pm SD / n (\%) \\
\hline Birth weight (gram) & 2330-4190 & 3380 & $3405 \pm 317$ \\
\hline NLR & $1.8-22.7$ & 4.2 & $4.8 \pm 2.8$ \\
\hline PLR & $22.4-744.4$ & 129.3 & $148.8 \pm 74.9$ \\
\hline Procedure & $\begin{array}{l}\text { Vaginal prostaglandin } \\
\text { Balloon dilation }\end{array}$ & & $\begin{array}{l}120(71.0 \%) \\
49(29.0 \%)\end{array}$ \\
\hline Delivery type & $\begin{array}{l}\text { Vaginal delivery } \\
\text { Cesarean section }\end{array}$ & & $\begin{array}{l}108(63.9 \%) \\
61(36.1 \%)\end{array}$ \\
\hline Sex & $\begin{array}{l}\text { Male } \\
\text { Female }\end{array}$ & & $\begin{array}{l}77(45.6 \%) \\
92(54.4 \%)\end{array}$ \\
\hline Apgar & $\begin{array}{l}\geq 7 \\
<7\end{array}$ & & $\begin{array}{l}142(84.0 \%) \\
27(16.0 \%)\end{array}$ \\
\hline
\end{tabular}

NLR: neutrophil-lymphocyte ratio; PLR: platelet-lymphocyte ratio. 
Table 2. The comparison of the data by Apgar scores.

\begin{tabular}{|c|c|c|c|c|}
\hline & & $\begin{array}{c}\text { Apgar } \geq 7 \\
\text { Mean } \pm \text { SD / n (\%) }\end{array}$ & $\begin{array}{c}\text { Apgar }<7 \\
\text { Mean } \pm \text { SD / n (\%) }\end{array}$ & p-value \\
\hline Weight (g) & & $3400 \pm 325$ & $3433 \pm 271$ & 0.617 \\
\hline NLR & & $4.2 \pm 2.2$ & $7.7 \pm 3.9$ & 0.000 \\
\hline PLR & & $144.0 \pm 73.6$ & $174.6 \pm 78.1$ & 0.007 \\
\hline Procedure & $\begin{array}{l}\text { Vaginal prostaglandin } \\
\text { Balloon dilation }\end{array}$ & $\begin{array}{l}101(71.1 \%) \\
41(28.9 \%)\end{array}$ & $\begin{array}{l}19(\% 70.4) \\
8(29.6 \%)\end{array}$ & 0.937 \\
\hline Delivery type & $\begin{array}{l}\text { Vaginal delivery } \\
\text { Cesarean section }\end{array}$ & $\begin{array}{l}99(69.7 \%) \\
43(30.3 \%) \\
\end{array}$ & $\begin{array}{c}9(33.3 \%) \\
18(66.7 \%) \\
\end{array}$ & 0.000 \\
\hline Sex & $\begin{array}{l}\text { Male } \\
\text { Female }\end{array}$ & $\begin{array}{l}63(44.4 \%) \\
79(55.6 \%)\end{array}$ & $\begin{array}{l}14(51.9 \%) \\
13(48.1 \%)\end{array}$ & 0.474 \\
\hline
\end{tabular}

NLR: neutrophil-lymphocyte ratio; PLR: platelet-lymphocyte ratio.

the immunity surveillance, and platelet-lymphocyte ratio (PLR) has a significant role in the cytokinedependent immune response. ${ }^{[16]}$ It was claimed that PLR is a sensitive marker for systemic inflammation in various cases. ${ }^{[17]}$ In a study performed in South Korea, NLR and PLR values were calculated $1.73 \pm 1.55$ and $133.7 \pm 85.6$, respectively in the women who are in healthy reproductive period. ${ }^{[20]}$ In another study performed to generate a nomogram during pregnancy,

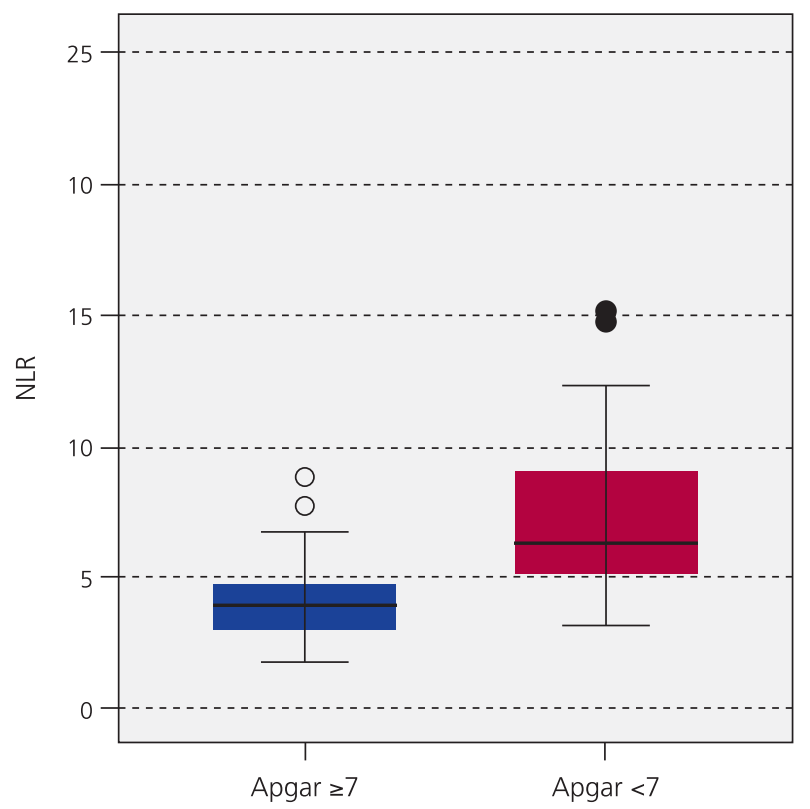

Fig. 1. The distribution graph of NLR-PLR.
NLR and PLR values were found $2.6 \pm 1$ and $136.3 \pm 44.3$ during the first trimester, $4.0 \pm 1.4$ and $144.6 \pm 47.1$ during the second trimester, and $3.5 \pm 1.2$ and $118.1 \pm 42$ during the third trimester, respectively. It was shown that both NLR and PLR reached the maximum values during the second trimester and that they had a positive correlation with the gestational age. ${ }^{[19]}$ As seen in the previous studies, slight elevations in NLR and PLR values during pregnancy are the part of natural course.

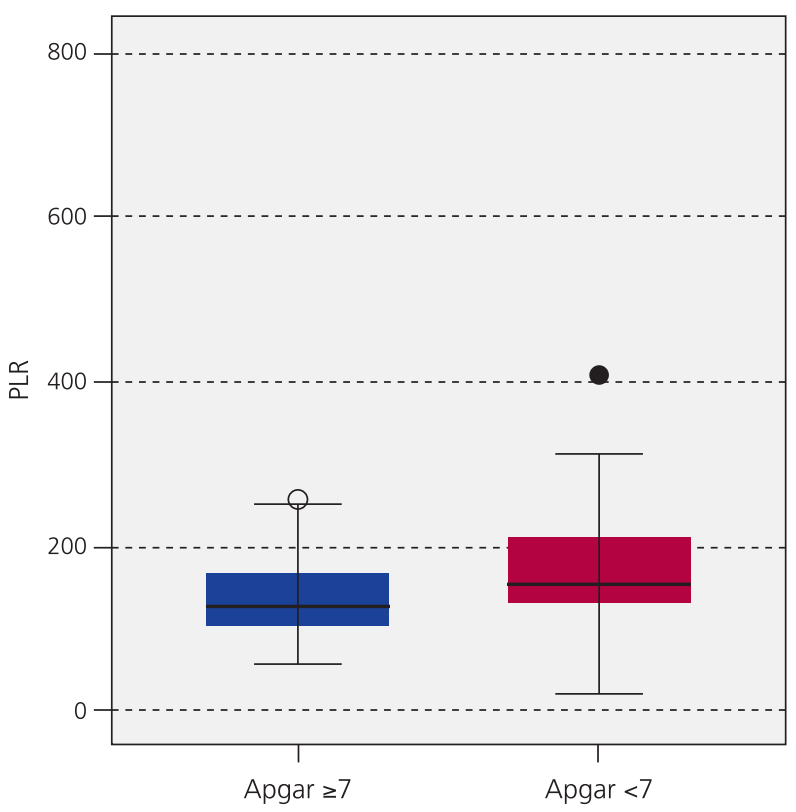


Previously, NLR and PLR were tested as the predictors of common gestational complications; however, it was seen that there were inconsistencies between the results. ${ }^{[1,1,17,21,22]}$ For instance, it was found that NLR was not predictive for pregnancy-related hypertension, ${ }^{[2]}$ but increased significantly in the preeclamptic patients. Similar inconsistencies were also reported in the studies testing NLR and PLR in the pregnant women with gestational diabetes. ${ }^{[1,21]}$ NLR was also evaluated in the inflammatory conditions complicating pregnancy and was suggested as an early indicator of acute pancreatitis during pregnancy and a potential marker for disease severity. ${ }^{[23]}$ It was shown that NLR has a better diagnostic performance than maternal serum C-reactive protein (CRP) in case of placental inflammatory response. High NLR helped to predict preterm labor even at normal CRP levels. ${ }^{[24]}$ These studies highlight the potential contribution of evaluating NLR in diagnostic difficulties during pregnancy.

Slight elevations in the inflammation is the usual part of a healthy pregnancy, but higher inflammation levels during pregnancy are associated with poor gestational outcomes. ${ }^{[25,26]}$ For instance, CRP concentrations in the circulation elevate slightly in healthy pregnant women; ${ }^{[27,28]}$ however, the concentrations higher than normal during the third trimester may help to predict low birth weight, preterm labor, chronic placental villitis and preeclampsia. ${ }^{[29-32]}$ Elevated inflammation during pregnancy is also associated with gestational diabetes ${ }^{[33]}$ and neonatal neurobehavioral disorder. ${ }^{[3+]}$ In our study, we found that inflammatory indicators such as NLR and PLR elevated in the newborns with Apgar score $<7$ in cases induced due to prolonged pregnancy although they did not have any comorbid condition. We believe that it may be secondary to a low level inflammation which is non-predicting clinically.

The mechanisms of action of the chronic inflammation leading to the development of gestational complications have been investigated. Primarily, the condition of low level chronic inflammation may be the expression of an abnormal immunity regulation during pregnancy which allows trophoblastic invasion and placentation in the women with polycystic ovary syndrome (PCOS), decreases maternal immunological suppression and increases the frequency and level of immune-mediated placental pathologies. ${ }^{[3,36]}$ In this sense, an increase has been observed recently in the placental lesion incidence in the microscopic analysis such as chronic villitis and intervillositis in the women with PCOS ${ }^{[36]}$ Palomba et al. found that elevated WBC, CRP and ferritin levels in the pregnant women with PCOS were secondary to the low level chronic inflammation, and that it was an increased risk for the obstetric/neonatal complications such as pregnancy-related hypertension, preeclampsia, gestational diabetes, antepartum hemorrhage and birth weight being large and/or small for gestational age in the presence of these indicators. ${ }^{[36]}$ It is believed that obesity also results in the poor obstetric effects and neonatal complications by causing chronic inflammation as in PCOS patients. In the study of Çintesun, the authors found that WBC, neutrophil and lymphocyte values which are directly associated with inflammation were significantly higher in the obese group during early pregnancy period. ${ }^{[3]}$ It was reported that the elevated WBC is associated with the impaired glucose metabolism, insulin resistance and type 2 diabetes, and high WBC levels lead to gestational diabetes. ${ }^{[38]}$ There are also other factors initiating and maintaining a low level inflammatory response than PCOS and obesity. These include aging, malnutrition and smoking. These factors may be the reasons in our patient group with elevated NLR and PLR levels. The clinical results of our findings are not clear and additional studies are needed.

The most important limitation of our study can be the failure of ruling out every variable that may affect Apgar score. We did not include the neonatal results and maternal data for the factors such as obesity and PCOS which may affect maternal NLR and PLR value. Other than that, we did not investigate the advanced maternal age, nutritional conditions and cholesterol levels as well as smoking habits which may be associated with the chronic inflammation of patients. We did not evaluate the relationship between NLR and PLR values and the duration from collecting blood samples to delivery, and did not perform any additional hemogram measurement.

The elevations in NLR and PLR values is the usual part of a healthy pregnancy, ${ }^{[19]}$ but extremely increased inflammation was found to be associated with poor postpartum and developmental outcomes in various populations. ${ }^{[25,26]}$

\section{Conclusion}

In conclusion, these markers may help clinicians to predict poor obstetric outcomes, and they are also cheap and practicable parameters technically. However, fur- 
ther analyses are needed with a wider population before reaching a final decision.

Conflicts of Interest: No conflicts declared.

\section{References}

1. Hilder L, Costeloe K, Thilaganathan B. Prolonged pregnancy: evaluating gestation-specific risks of fetal and infant mortality. Br J Obstet Gynaecol 1998;105:169-73. [PubMed] [CrossRef]

2. NICE. Induction of labour: Guideline CG70. London: NICE; 2008.

3. Berglund S, Pettersson H, Cnattingius S, Grunewald C. How often is a low Apgar score the result of substandard care during labour? BJOG 2010;117:968-78. [PubMed] [CrossRef]

4. Casey BM, McIntire DD, Leveno KJ. The continuing value of the Apgar score for the assessment of newborn infants. N Engl J Med 2001;344:467-71. [PubMed] [CrossRef]

5. Papile LA. The Apgar score in the 21st century. N Engl J Med 2001;344:519-20. [PubMed] [CrossRef]

6. Committee on Obstetric Practice American Academy of Pediatrics - Committee on Fetus and Newborn. Committee Opinion No. 644: the Apgar score. Obstet Gynecol 2015;126: e52-5. [PubMed] [CrossRef]

7. Chen J, Qu X, Li Z, Zhang D, Hou L. Peak neutrophil-tolymphocyte ratio correlates with clinical outcomes in patients with severe traumatic brain injury. Neurocrit Care 2019;30: 334-9. [PubMed] [CrossRef]

8. Seropian IM, Romeo FJ, Pizarro R, Vulcano NO, Posatini RA, Marenchino RG, et al. Neutrophil-to-lymphocyte ratio and platelet-to-lymphocyte ratio as predictors of survival after heart transplantation. ESC Heart Fail 2018;5:149-56. [PubMed] [CrossRef]

9. Lee SK, Lee SC, Park JW, Kim SJ. The utility of the preoperative neutrophil-to-lymphocyte ratio in predicting severe cholecystitis: a retrospective cohort study. BMC Surg 2014;14: 100. [PubMed] [CrossRef]

10. Haram A, Boland MR, Kelly ME, Bolger JC, Waldron RM, Kerin MJ. The prognostic value of neutrophil-to-lymphocyte ratio in colorectal cancer: a systematic review. J Surg Oncol 2017;115:470-9. [PubMed] [CrossRef]

11. Ethier JL, Desautels DN, Templeton AJ, Oza A, Amir E, Lheureux $\mathrm{S}$. Is the neutrophil-to-lymphocyte ratio prognostic of survival outcomes in gynecologic cancers? A systematic review and meta-analysis. Gynecol Oncol 2017;145:584-94. [PubMed] [CrossRef]

12. Verit FF, Cetin O, Yildirim O, Keskin S, Yucel O, Yalcinkaya S. Neutrophil to lymphocyte ratio is superior to platelet to lymphocyte ratio as an early predictor of moderate/severe ovarian hyperstimulation syndrome. J Obstet Gynaecol 2014; 34:639-43. [PubMed] [CrossRef]

13. Ilhan G, Atmaca FFV, Altan E, Zebitay AG, Sozen H, Akyol $\mathrm{H}$, et al. Evaluation of neutrophil-lymphocyte ratio, plateletlymphocyte ratio and red blood cell distribution width-platelet ratio for diagnosis of premature ovarian insufficiency. J Family Reprod Health 2016;10:211-6. [PubMed]
14. Tokmak A, Yildirim G, Öztaş E, Akar S, Erkenekli K, Gülşen $\mathrm{P}$, et al. Use of neutrophil-to-lymphocyte ratio combined with CA-125 to distinguish endometriomas from other benign ovarian cysts. Reprod Sci 2016;23:795-802. [PubMed] [CrossRef]

15. Kurt RK, Güler A, Silfeler DB, Ozçil MD, Karateke A, Hakverdi AU. Relation of inflammatory markers with both presence and severity of hyperemesis gravidarum. Ginekol Pol 2014;85:589-93. [PubMed] [CrossRef]

16. Sargin MA, Yassa M, Taymur BD, Celik A, Ergun E, Tug N. Neutrophil-to-lymphocyte and platelet-to-lymphocyte ratios: are they useful for predicting gestational diabetes mellitus during pregnancy? Ther Clin Risk Manag 2016;12:657-65. [PubMed] [CrossRef]

17. Serin S, Avci F, Ercan O, Kostu B, Bakacak M, Kiran H. Is neutrophil/lymphocyte ratio a useful marker to predict the severity of pre-eclampsia? Pregnancy Hypertens 2016;6:225. [PubMed] [CrossRef]

18. Kirbas A, Biberoglu E, Daglar K, Iskender C, Erkaya S, Dede $\mathrm{H}$, et al. Neutrophil-to-lymphocyte ratio as a diagnostic marker of intrahepatic cholestasis of pregnancy. Eur J Obstet Gynecol Reprod Biol 2014;180:12-5. [PubMed] [CrossRef]

19. Hershko Klement A, Hadi E, Asali A, Shavit T, Wiser A, Haikin E, et al. Neutrophils to lymphocytes ratio and platelets to lymphocytes ratio in pregnancy: a population study. PLoS One 2018;13(5):e0196706. [PubMed] [CrossRef]

20. Lee JS, Kim NY, Na SH, Youn YH, Shin CS. Reference values of neutrophil-lymphocyte ratio, lymphocyte-monocyte ratio, platelet-lymphocyte ratio, and mean platelet volume in healthy adults in South Korea. Medicine (Baltimore) 2018;97: e11138. [PubMed] [CrossRef]

21. Aktulay A, Engin-Ustun Y, Ozkan MS, Erkaya S, Kara M, Kaymak O, et al. Gestational diabetes mellitus seems to be associated with inflammation. Acta Clin Croat 2015;54:4758. [PubMed]

22. Yucel B, Ustun B. Neutrophil to lymphocyte ratio, platelet to lymphocyte ratio, mean platelet volume, red cell distribution width and plateletcrit in preeclampsia. Pregnancy Hypertens 2017;7:29-32. [PubMed] [CrossRef]

23. Ilhan M, Ilhan G, Gok AFK, Bademler S, Verit Atmaca F, Ertekin C. Evaluation of neutrophil-lymphocyte ratio, platelet-lymphocyte ratio and red blood cell distribution width-platelet ratio as early predictor of acute pancreatitis in pregnancy. J Matern Fetal Neonatal Med 2016;29:147680. [PubMed] [CrossRef]

24. Kim MA, Lee YS, Seo K. Assessment of predictive markers for placental inflammatory response in preterm births. PloS One 2014;9(10):e107880. [PubMed] [CrossRef]

25. Challis JR, Lockwood CJ, Myatt L, Norman JE, Strauss JF, Petraglia F. Inflammation and pregnancy. Reprod Sci 2009;16: 206-15. [PubMed] [CrossRef]

26. Romero R, Gotsch F, Pineles B, Kusanovic JP. Inflammation in pregnancy: its roles in reproductive physiology, obstetrical complications, and fetal injury. Nutr Rev 2007;65:194202. [PubMed] [CrossRef] 
27. Watts DH, Krohn MA, Wener MH, Eschenbach DA. C-reactive protein in normal pregnancy. Obstet Gynecol 1991;77: 176-80. [PubMed] [CrossRef]

28. Kuzawa CW, Adair LS, Borja J, McDade TW. C-reactive protein by pregnancy and lactational status among Filipino young adult women. Am J Hum Biol 2013;25:131-4. [PubMed] [CrossRef]

29. Lowe LP, Metzger BE, Lowe WL Jr, Dyer AR, McDade TW, McIntyre HD. Inflammatory mediators and glucose in pregnancy: results from a subset of the Hyperglycemia and Adverse Pregnancy Outcome (HAPO) Study. J Clin Endocrinol Metab 2010;95:5427-34. [PubMed] [CrossRef]

30. Sorokin Y, Romero R, Mele L, Wapner RJ, Iams JD, Dudley DJ, et al. Maternal serum interleukin-6, C-reactive protein, and matrix metalloproteinase- 9 concentrations as risk factors for preterm birth $<32$ weeks and adverse neonatal outcomes. Am J Perinatol 2010;27:631-40. [PubMed] [CrossRef]

31. Ernst LM, Grobman WA, Wolfe K, Huang MH, McDade TW, Holl JL, et al. Biological markers of stress in pregnancy: associations with chronic placental inflammation at delivery. Am J Perinatol 2013;30:557-64. [PubMed] [CrossRef]

32. Teran E, Escudero C, Calle A. C-reactive protein during normal pregnancy and preeclampsia. Int J Gynaecol Obstet 2005; 89:299-300. [PubMed] [CrossRef]

33. Retnakaran R, Hanley AJG, Raif N, Connelly PW, Sermer M, Zinman B. C-reactive protein and gestational diabetes: the central role of maternal obesity. J Clin Endocrinol Metab 2003;88:3507-12. [PubMed] [CrossRef]

34. Ponzio NM, Servatius R, Beck K, Marzouk A, Kreider T. Cytokine levels during pregnancy influence immunological profiles and neurobehavioral patterns of the offspring. Ann $\mathrm{N}$ Y Acad Sci 2007;1107:118-28. [PubMed] [CrossRef]

35. Vanky E, Salvesen KA, Asberg A, Carlsen SM. Haemoglobin, C-reactive protein and androgen levels in uncomplicated and complicated pregnancies of women with polycystic ovary syndrome. Scand J Clin Lab Invest 2008;68: 421-6. [PubMed] [CrossRef]

36. Palomba S, Russo T, Falbo A, Di Cello A, Amendola G, Mazza R, et al. Decidual endovascular trophoblast invasion in women with polycystic ovary syndrome: an experimental case-control study. J Clin Endocrinol Metab 2012;97:24419. [PubMed] [CrossRef]

37. İncesu Çintesun FN. The association between obesity and hematologic inflammatory markers in the first trimester pregnancies. Perinatal Journal 2020;28:17-22. [CrossRef]

38. Pattanathaiyanon $\mathrm{P}$, Phaloprakarn C, Tangjitgamol S. Comparison of gestational diabetes mellitus rates in women with increased and normal white blood cell counts in early pregnancy. J Obstet Gynaecol Res 2014;40:976-82. [PubMed] [CrossRef] 